\title{
OPEN Detection of Begomovirus in chilli and tomato plants using functionalized gold nanoparticles
}

\author{
R. Lavanya $\oplus^{\circledR}$ \& V. Arun ${ }^{凶}$
}

Begomoviruses are a major class of Geminiviruses that affects most dicotyledonous plants and causes heavy economic losses to farmers. Early detection of begomovirus is essential to control the spread of the disease and prevent loss. Many available detection methods like ELISA, immunosorbent electron microscopy, PCR or qPCR require expertise in handling sophisticated instruments, complex data interpretation and costlier chemicals, enzymes or antibodies. Hence there is a need for a simpler detection method, here we report the development of a visual detection method based on functionalized gold nanoparticles (AuNP assay). The assay was able to detect up to $500 \mathrm{ag} / \mu \mathrm{l}$ of begomoviral DNA (PTZCCPp3, a clone carrying partial coat protein gene) suspended in MilliO water. Screening of chilli plants for begomoviral infection by PCR (Deng primers) and AuNP assay showed that AuNP assay (77.7\%) was better than PCR (49.4\%). The AuNP assay with clccpi1 probe was able to detect begomoviral infection in chilli, tomato, common bean, green gram and black gram plants which proved the utility and versatility of the AuNP assay. The specificity of the assay was demonstrated by testing with total DNA from different plants that are not affected by begomoviruses.

Plant pathogens and pests are some of the major factors that limit crop productivity. Infection could be detected easily by visual inspection if the characteristic symptoms of the disease are clearly visible. However many factors play a major role in identification of infection like viral strain, cultivar, time of infection and other environmental factors ${ }^{1}$. Geminiviridae and Potyviridae are the two largest families that constitute important plant viruses, which are highly devastating phytopathogens worldwide ${ }^{2,3}$. The family Geminiviridae was established in $1978^{4}$ and consists of 9 genera: Becurtovirus, Capulavirus, Curtovirus, Eragrovirus, Grablovirus, Mastrevirus, Topocuvirus, Turncurtovirus [Monopartite genome] and Begomovirus [Bipartite genome] ${ }^{5-7}$. The genetic material of geminiviruses is ssDNA and has either a monopartite (DNA-A) or bipartite (DNA-A and DNA-B) genome. Of the many geminiviruses infecting economically important crops, begomoviruses are one of the most destructive viruses and are transmitted by whitefly vector Bemisia tabaci $i^{8-10}$.

Capsicum annuum (Chilli) and Solanum lycopersicum (Tomato) plants belong to the family Solanaceae and are grown in tropical countries. It is a family of flowering plants, consisting of many important crops like potatoes, tomatoes, peppers, tobacco, petunia and other crops of regional significance ${ }^{11,12}$. Plants belonging to the Solanaceae family are heavily affected by viruses and begomoviruses are the major pathogen ${ }^{8,13-16}$. Begomovirus symptoms in plants range from symptomless to different degrees of stunting and curling, distortion, mosaic, mottling, vein yellowing of leaves, flower abortion, small and unmarketable fruits ${ }^{17}$. India is one of the top producers of chilli and tomato in the world and are cultivated across the country throughout the year ${ }^{18}$. Begomoviral infection has been reported in different states of India in chilli and tomato plants and were shown to cause severe losses $^{19}$. Begomovirus infecting pepper (chilli) and tomato plants have narrow host ranges and were shown to infect plants of other families, e.g., Fabaceae [common bean and soybean (Glycine max)] and Cucurbitaceae ${ }^{20,21}$.

One of the basic requirements for the elimination and spread of viruses is detection of the presence of viruses at the earliest possible stage in plants ${ }^{22}$. Many methods are available for the detection of plant viruses which could be classified into protein-based methods (immunotechniques) or nucleic acid-based methods (molecular methods). The various immunotechniques include enzyme linked immunosorbent assay (ELISA) ${ }^{23-25}$, immunoblotting ${ }^{26}$, immunosorbent electron microscopy ${ }^{27,28}$ and precipitin tests ${ }^{29}$. These methods rely on specific interaction of antibody (monoclonal or polyclonal) with viral antigens (coat protein) and hence are prone to false-negative results at low viral titers. The limitations of these methods also include cross-reactivity with similar antigens resulting in false-positive results. The production of antibodies is tedious, expensive and requires expertise. 

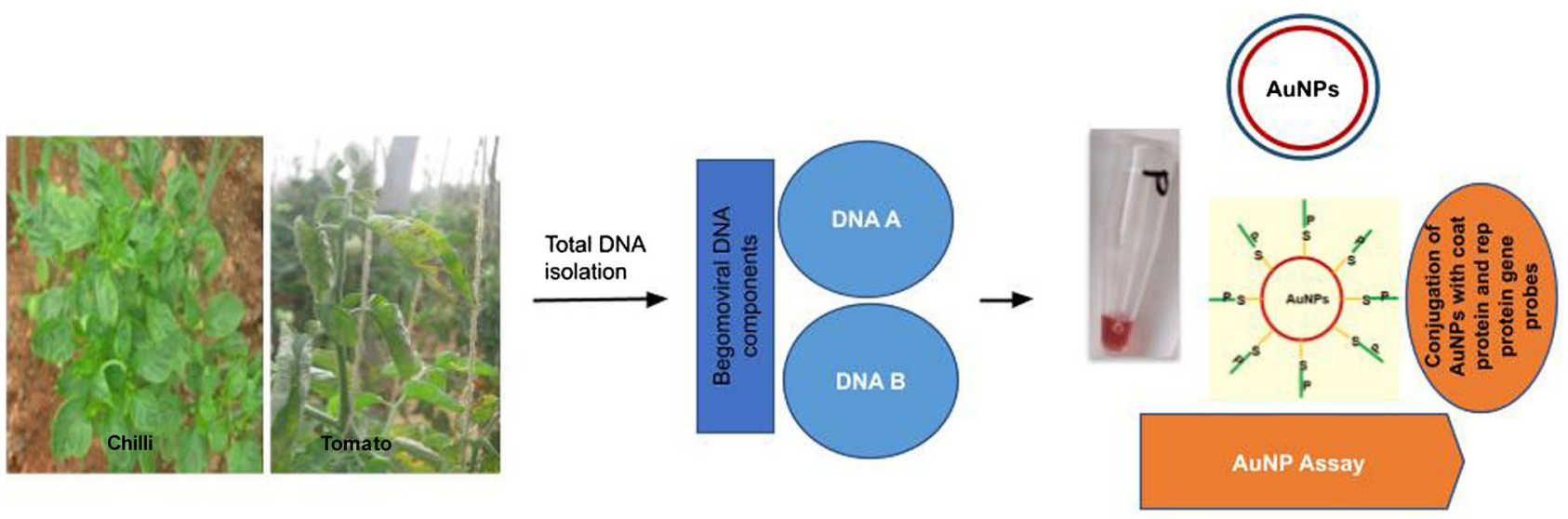

Figure 1. Schematic representation of the AuNP assay proposed in this work. Total DNA would be isolated from plant samples and screened for the presence of begomoviruses using the functionalized AuNPs.

Molecular methods like $\mathrm{PCR}^{30-33}$, Nucleic Acid Spot Hybridization (NASH) assay ${ }^{34-40}$ depend on viral nucleic acids and viral specific primers or probes. PCR is the most commonly used detection technique for begomoviruses and primers were primarily designed on coat protein and replicase genes ${ }^{41}$. Among the viral proteins, coat protein has been shown to be important for the infection and propagation of the virus. This gene was reported to be conserved among begomoviruses and many primers designed in this region were utilized for PCR based detection of begomovirus ${ }^{42}$. The major advantages of molecular techniques are specificity, sensitivity, faster detection and multiplexing ${ }^{43,44}$. Though most molecular techniques are robust, there are drawbacks like nonspecific amplification, inhibition of polymerase activity due to the presence of phenolics, polysaccharides in the nucleic acids $^{45}$

Simple and convenient technologies for the identification of chemical and biological species are of great significance in environmental monitoring, public health and disease diagnosis ${ }^{46,47}$. Here we report the development of functionalized gold nanoparticles (AuNPs) based visual detection method that rely on the hybridization principle. Gold nanoparticles (AuNPs) have been routinely used for the development of visual detection methods for many pathogens due to their unique colour properties and tunable localized surface plasmon resonance $(\mathrm{SPR})^{48}$. Surface plasmon resonance has been shown to be dependent on NP (nanoparticle) composition, size and shape ${ }^{49,50}$.

Detection methods based on functionalized nanoparticles were found to be highly sensitive with faster turnover than the other methods like PCR, ELISA. Early detection of plant pathogens is critical for the management of infections in plants as it would result in better segregation of healthy plants and infected plants at the earliest, thus preventing the spread of disease in a farm or field ${ }^{51}$. Recently, a visual DNA method using integrated Recombinase Polymerase amplification (RPA) and a AuNP probe has been reported for detection of tomato yellow leaf curl virus and was found to be highly sensitive and stable ${ }^{52}$. In our lab, we had developed a method for detection of Banana Bunchy Top Virus (BBTV) using functionalized AuNPs ${ }^{53}$. In this work, we demonstrated the applicability of functionalized AuNPs in the detection of begomoviruses in plants and an Indian patent has been filed (Application No: 201941007582) (Fig. 1).

\section{Results}

DNA isolation from chilli and tomato leaves. A total of 99 chilli samples and 79 tomato samples were used in this study and total DNA was isolated using the Dellaporta method. The total DNA obtained from chilli and tomato plants were analyzed by agarose gel electrophoresis and Nanodrop. The DNA obtained from tomato samples had brownish tinge and were viscous, whereas DNA from chilli samples had aqueous consistency and were transparent. Total DNA from other plants (Phaseolus vulgaris, Vigna radiata, Vigna mungo, Indigofera aspalathoides, Plectranthus amboinicus and Catharanthus roseus) used in this study also had good quality.

Screening of chilli and tomato plants by PCR for begomovirus infection. The chilli and tomato samples (99 No's and 79 No's) were then screened for begomovirus infection by PCR using Deng primers. PCR was also done for housekeeping gene 18S rRNA for both chilli and tomato samples and amplification was observed for chilli samples but not for tomato samples (data not shown) ${ }^{54}$. Out of 99 chilli DNA samples, 49 samples were found to be positive for PCR with Deng primers (amplicon of $\cong 530 \mathrm{bp}$ ) (Fig. $2 \mathrm{a}$ ). PCR analysis of a few tomato samples using Deng primers were negative (Fig. 2b).

Cloning and sequencing of coat protein region of begomovirus. The begomoviral DNA was amplified from chilli samples using Deng A and Deng B primers and the PCR positive chilli plants (49 samples) had an amplicon of $\sim 530 \mathrm{bp}$. One of the PCR products was cloned and sequenced using M13 sequencing primers. The sequence obtained from the clone, pTZCCPp3 was then analyzed by blastn and was found to be coat protein (partial) of chilli leaf curl virus ${ }^{54}$. The sequence was then submitted to Genbank with the accession number MH500267 (Fig. 3). 
CHILLI PLANTS

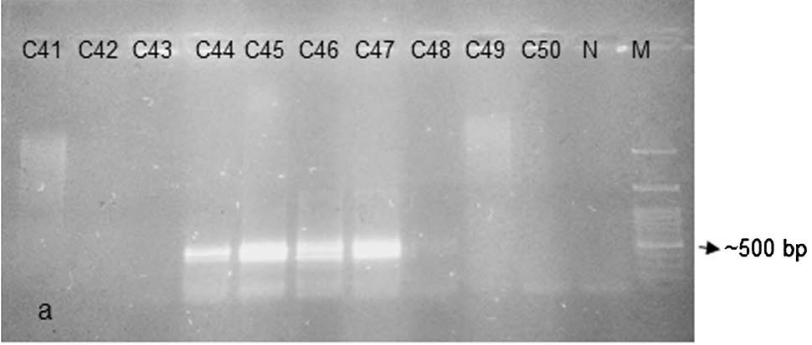

Lanes 1 to 10: Chilli DNA samples $\mathrm{C} 41$ to $\mathrm{C} 50$ $\mathrm{N}$ - Negative; $\mathrm{M}-1 \mathrm{~Kb}$ ladder
TOMATO PLANTS

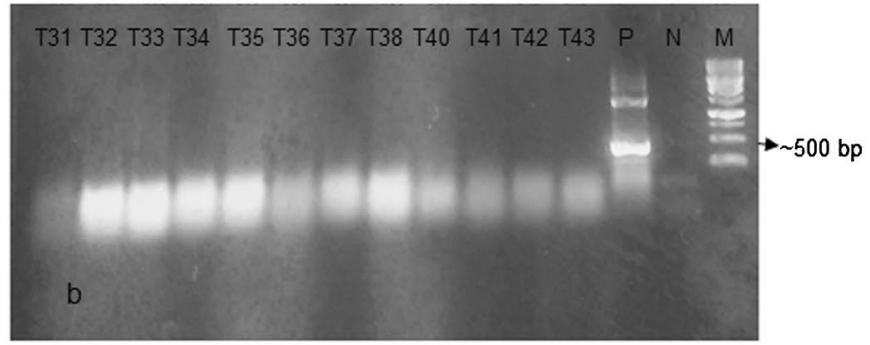

Lanes 1 to 12: Tomato DNA samples isolated by Dellaporta method $P$ - Positive Plasmid DNA; $N$ - Negative; $M$ - 1 Kb ladder

Figure 2. Screening of plants for the presence of begomovirus by PCR using Deng primers (Deng et al., 1994). (a) Lanes 1 to 10: Chilli DNA samples C41 to C50; N-Negative; M-1 Kb DNA ladder. (b) Lanes 1 to 12: Tomato DNA samples isolated by Dellaporta method; $P$ positive plasmid DNA; $N$ negative; $\mathrm{M}-1 \mathrm{~Kb}$ DNA ladder.

\section{Chilli leaf curl virus clone pTZCCPp3 pre-coat protein (V2) gene, complete cds; and coat protein (V1) gene, partial cds}

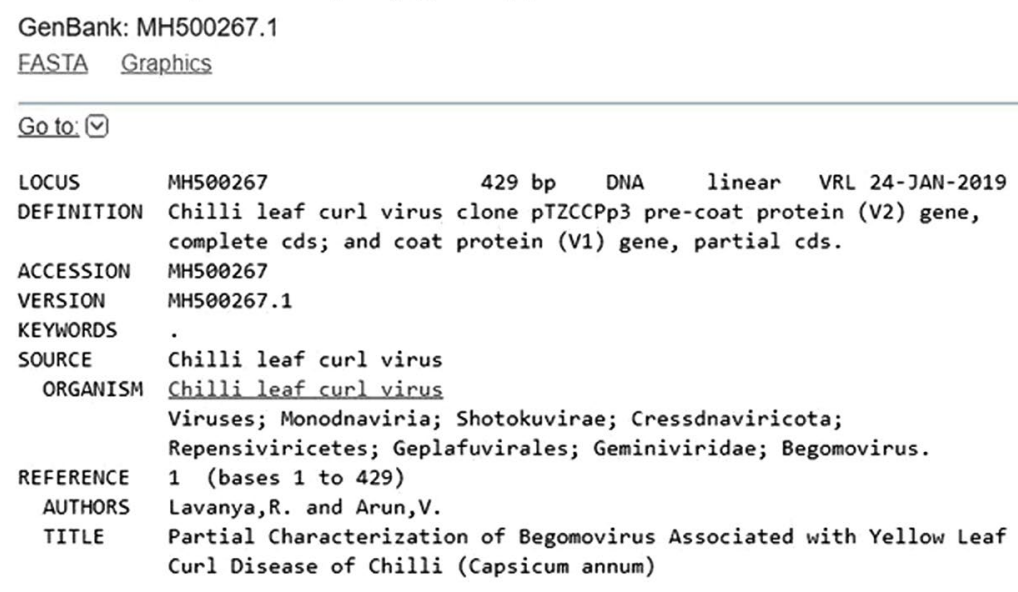

Figure 3. Chilli leaf curl viral coat protein gene (partial) obtained in this study.
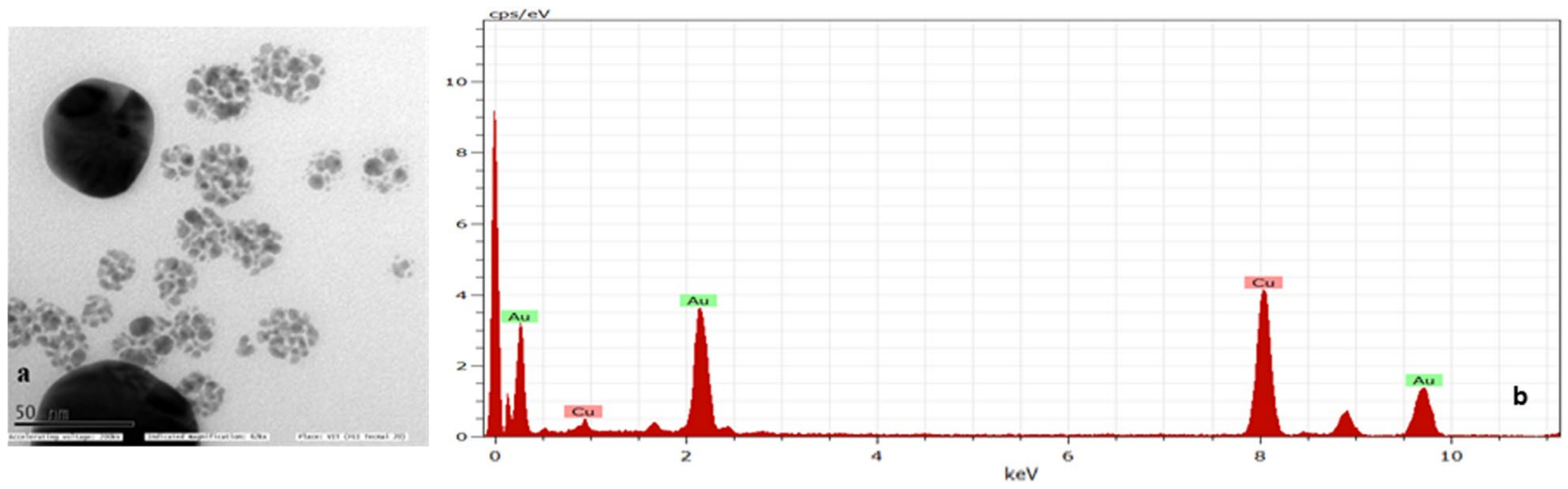

Figure 4. Microscopic and spectroscopic analysis of AuNPs. (a) Transmission Electron Micrograph (TEM) of AuNPs. (b) Energy Dispersive X-ray (EDX) spectroscopic analysis of synthesized AuNPs.

Synthesis and conjugation of AuNPs with clccpi1, chrppro1 and torppro1 probes. AuNPs synthesized by citrate reduction method were cherry red in colour and were further characterized by TEM and EDX (Fig. 4a,b). The size of the unmodified AuNPs was found to be $\cong 20 \mathrm{~nm}$ and the elemental composition analysis showed the presence of gold. Gold nanoparticles were then conjugated with thiolated probes (clccpil thiol, chrpprol thiol and torpprol thiol) by salt-ageing method and were found to retain the red colour. The average size 


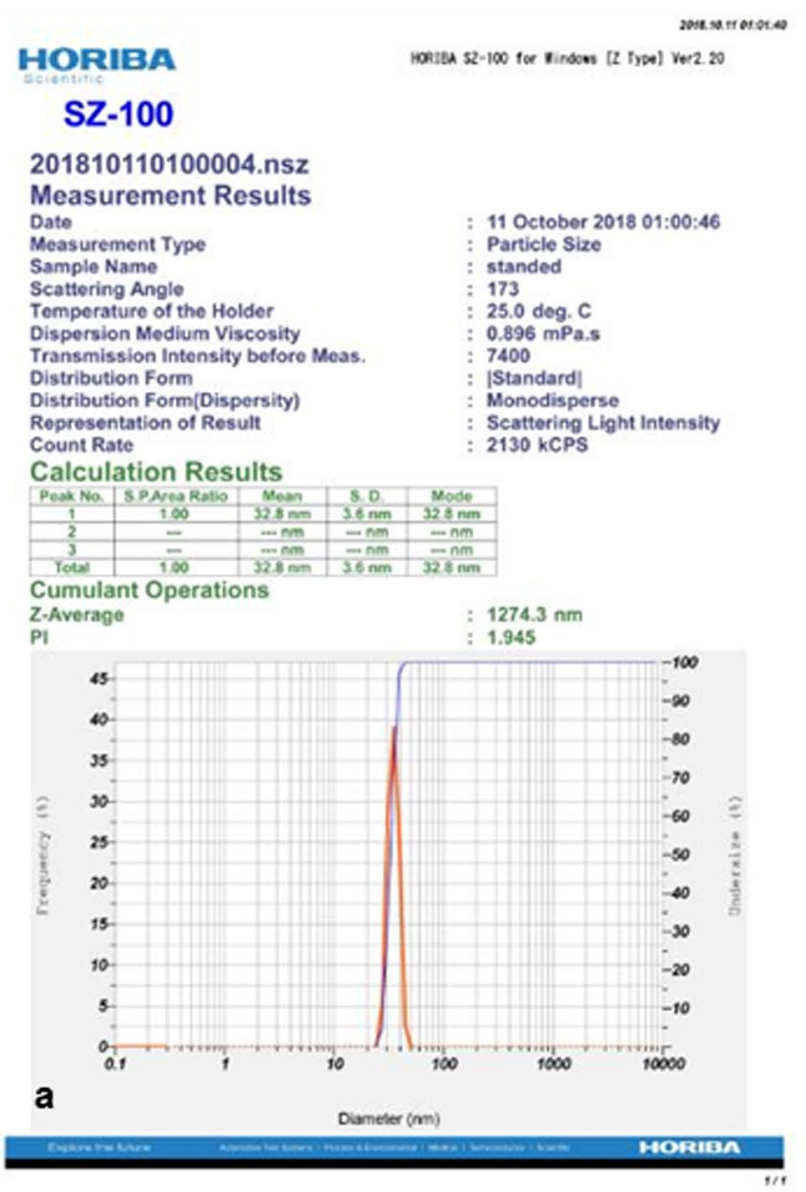

\section{HORIBA}

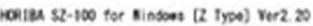

\section{SZ-100}

\section{Measurement Results}

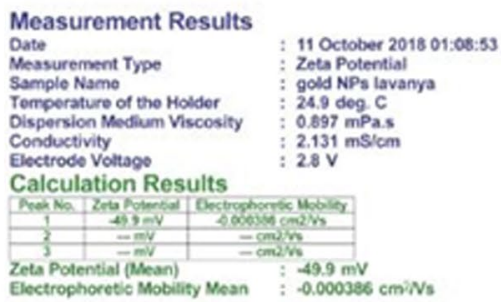

Figure 5. (a) Particle size analysis of functionalized AuNPs. (b) Zeta potential of functionalized AuNPs.

of functionalized gold nanoparticles was found to be $\cong 32.8 \mathrm{~nm}$ and the Zeta potential of functionalized gold nanoparticles was found to be $-49.9 \mathrm{mV}$ (Fig. 5a,b).

Screening of plants for begomoviral infection by AuNP assay. Surface plasmon resonance property of the functionalized gold nanoparticles was utilized for the development of AuNP assay. The reaction mixture consisted of template DNA (total DNA) from plants, functionalized AuNPs and salt. When the samples retained the red colour, it indicated the presence of begomovirus whereas change of colour from red to purple indicated the absence of begomovirus. The red colour of functionalized AuNPs in the presence of viral DNA was due to prevention of aggregation of AuNPs by the dsDNA when salt was added. In the absence of viral DNA, the functionalized AuNPs (ssDNA) are freely available for interaction with salt thereby resulting in aggregation (purple colour) $)^{55}$ (Fig. 6).

Chilli plants. The AuNP assay was performed in duplicates for all the 99 chilli samples. AuNP assay was carried out with three sets of probes (clccpil thiol, chrpprol thiol and chrppro1). Data of the AuNP assay of chilli samples with clccpil thiol probe and chrpprol thiol probe was provided (Fig. 7a,b). Out of 99 samples, 77 samples were found to be positive with AuNP assay (clccpil thiol and chrpprol thiol probes), whereas 70 samples were positive with chrppro1 probe (non-thiolated). PCR (Deng primers) analysis detected only 49 samples as positives (Fig. 7c).

Tomato plants. The AuNP assay was performed in duplicates for 79 tomato samples. The AuNP assay was carried out with three sets of probes (torpprol thiol, torpprol and clccpil thiol). Data of the AuNP assay of tomato samples with clccpil thiol probe and torppro1 thiol probes was provided (Fig. 8a,b). Out of 79 samples, 43 samples were found to be positive with AuNP assay (clccpil thiol probe and torpprol thiol probes) and 39 samples were positive with torpprol probe (Fig. 8c).

Sensitivity and specificity of the AuNP assay. To test the sensitivity of the AuNP assay with clccpil thiol probe, plasmid (pTZCCPp3) carrying partial coat protein region of begomovirus was diluted to different concentrations $(1 \mathrm{ng} / \mu \mathrm{l}$ to $1 \mathrm{ag} / \mu \mathrm{l})$ using Milli Q water and assayed. Similar concentrations were also screened by PCR using Deng primers. The AuNP assay was able to detect plasmid up to $500 \mathrm{ag} / \mu \mathrm{l}$, whereas PCR detected 


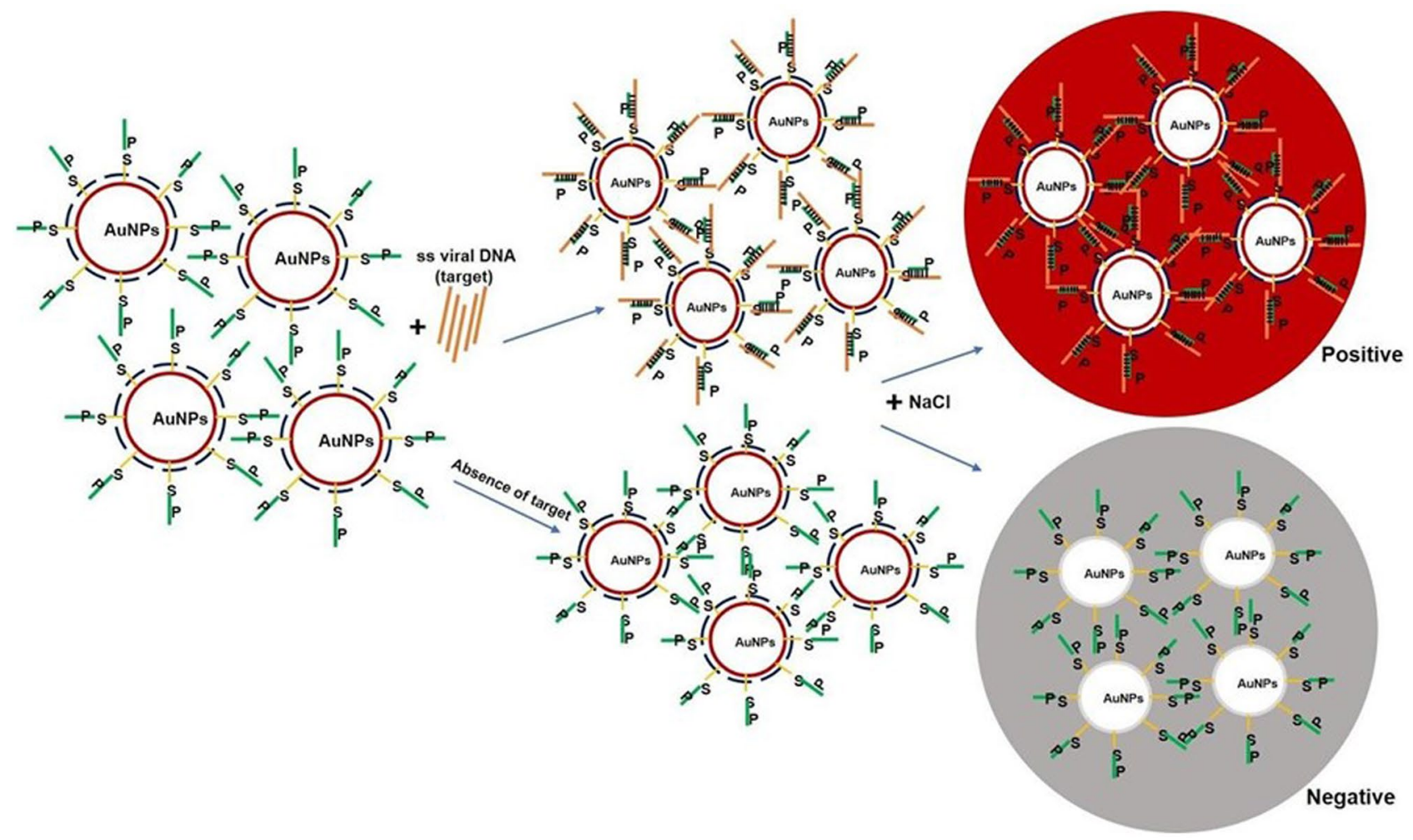

Figure 6. Schematic illustration of the principle of the AuNP assay for begomoviral detection. In the presence of viral DNA (target) the functionalized AuNPs retain red colour when $\mathrm{NaCl}$ was added as dsDNA (viral DNA + Probe DNA) prevents aggregation of the AuNPs. In the absence of viral DNA, functionalized AuNPs aggregate and turn purple due to the neutralization of electron cloud of AuNPs by the salt ${ }^{55}$. S-thiol linkage; P-probe.
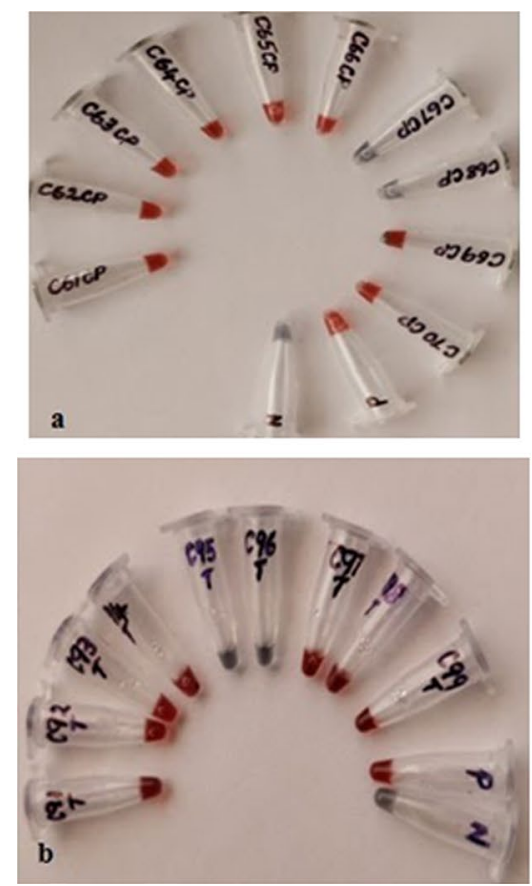

Comparison of PCR analysis (Deng primers) and AuNP assay (chrppro1 thiol, clccpi1 thiol and chrppro1 probes) in chilli plants (Total No. of samples - 99) 100

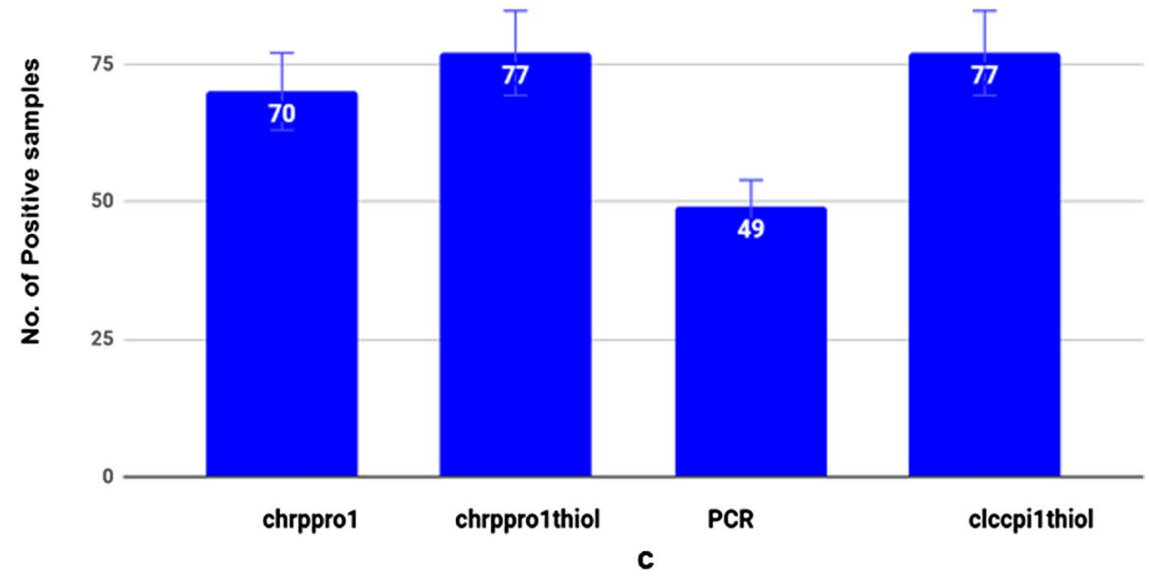

Figure 7. Detection of begomovirus in chilli samples using functionalized AuNPs. (a) With clccpi1 thiol probe; plant DNA (C71 to C80); positive (P) - begomovirus infected chilli DNA; N-healthy chilli DNA. (b) With chrppro1 thiol probe; plant DNA (C28 to C40); positive (P) - begomovirus infected chilli DNA; N-healthy chilli DNA. (c) Comparison of PCR and AuNP assay with different probes for chilli samples. 


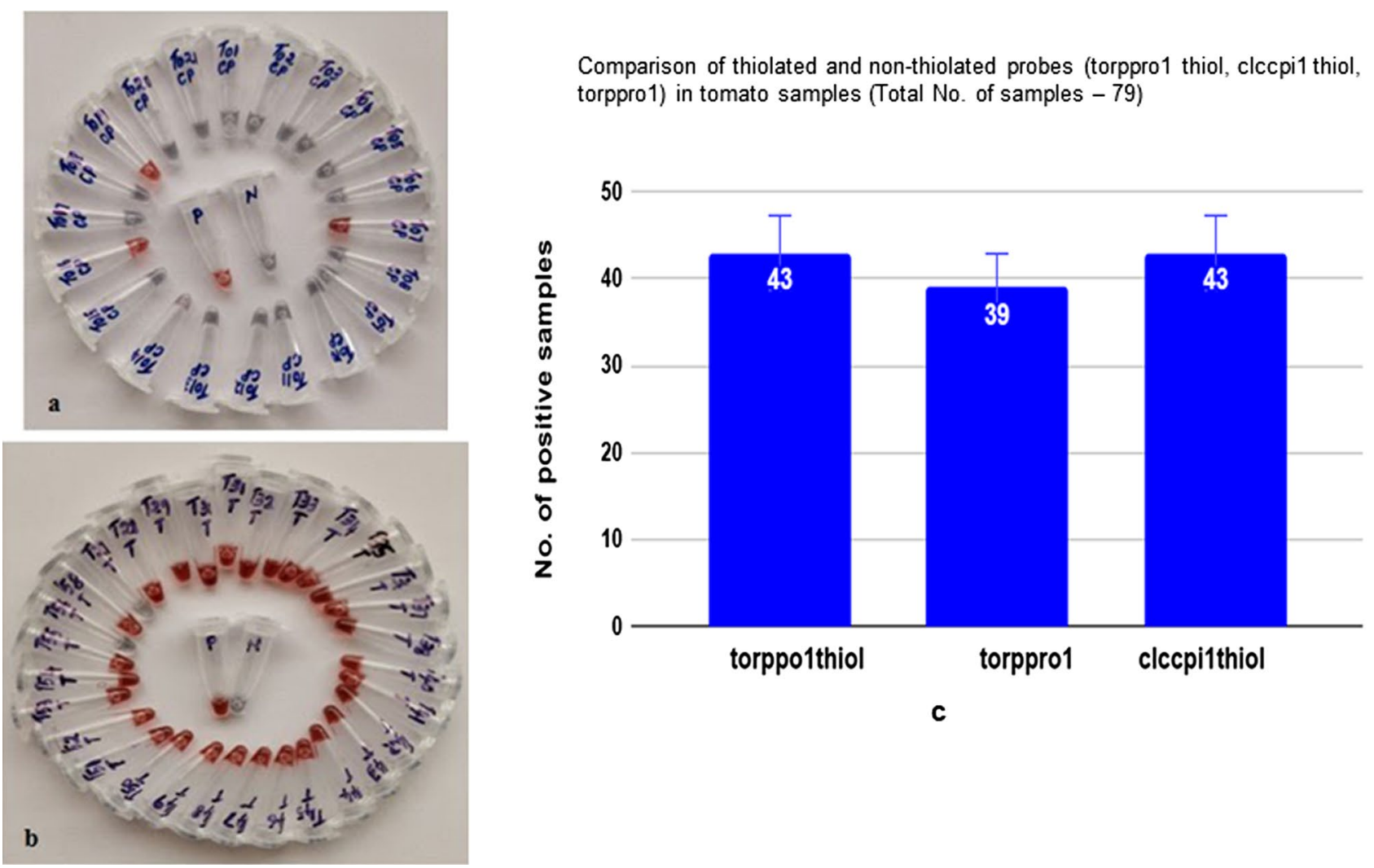

Figure 8. Detection of begomovirus in tomato plants using functionalized AuNPs. (a) With clccpil thiol probe, plant DNA (T27 to T38; T40 to T56 \& T58), positive (P) - begomovirus infected tomato DNA, N-healthy tomato DNA. (b) With torppro1 thiol probe, plant DNA (To1 to To21), positive (P) - begomovirus infected tomato DNA, N-healthy tomato DNA. (c) Comparison of AuNP assay with different probes for tomato samples.
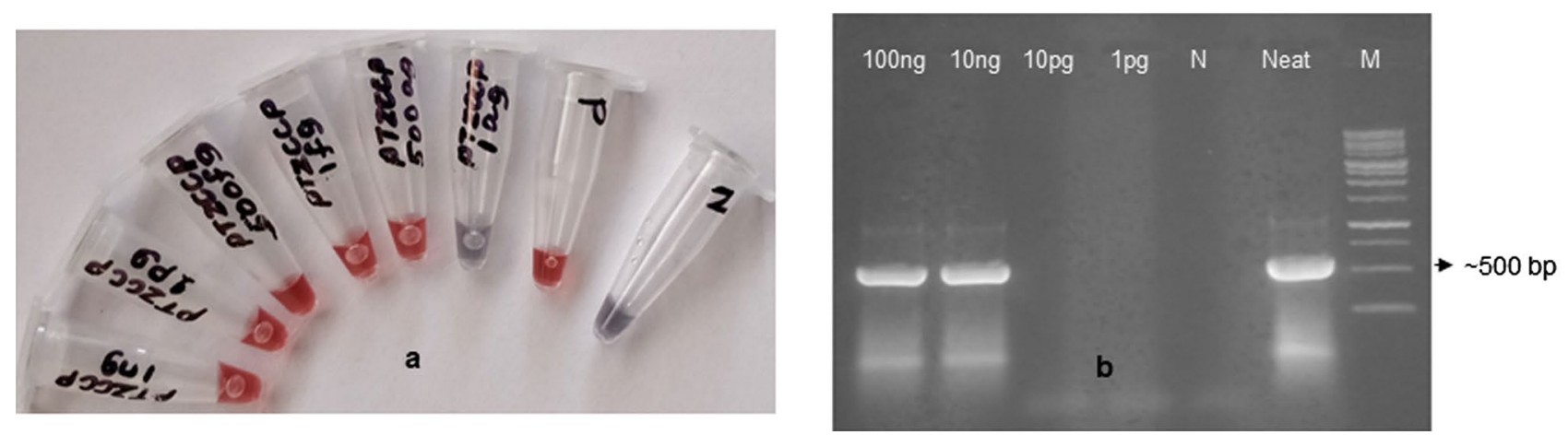

Figure 9. Comparison of the sensitivity of the AuNP assay and PCR (M13 primers) using different concentrations of plasmid (pTZCCPp3) diluted with Milli Q water. (a) AuNP assay with clccpil thiol probe was able to detect plasmid up to $500 \mathrm{ag} / \mu \mathrm{l}$. (b) PCR was able to detect plasmid up to $10 \mathrm{ng} / \mu \mathrm{l}$.

plasmid up to $10 \mathrm{ng} / \mu \mathrm{l}$ (Fig. 9a,b). The specificity of the AuNP assay with clccpil thiol probe was tested with total DNA from three plants belonging to different genera (Indigofera aspalathoides, Plectranthus amboinicus and Catharanthus roseus) that are not affected by begomovirus were chosen and AuNP assay was found to be negative (Fig. 10a).

Versatility of the AuNP assay. Symptomatic and asymptomatic samples (4 Nos.) of common bean (Phaseolus vulgaris) were collected from Chennai, Tamil Nadu. Begomovirus infected plants (Vigna mungo and Vigna radiata) were obtained from Tamil Nadu Agricultural University, India (Dr. K K Kumar, Department of Plant Biotechnology) and served as positive control. The AuNP assay with clccpil thiol probe was performed with total DNA from plants belonging to the Fabaceae family [Common bean (Phaseolus vulgaris $[\mathrm{n}=4]$ ), mung bean (Vigna radiata, $[\mathrm{n}=1]$ ) and black gram (Vigna mungo, $[\mathrm{n}=1])]$. Of the 4 common bean samples, 2 were found to be positive by PCR and AuNP assay. The PCR analysis with Deng primers showed an amplicon of $\sim 530$ bp 

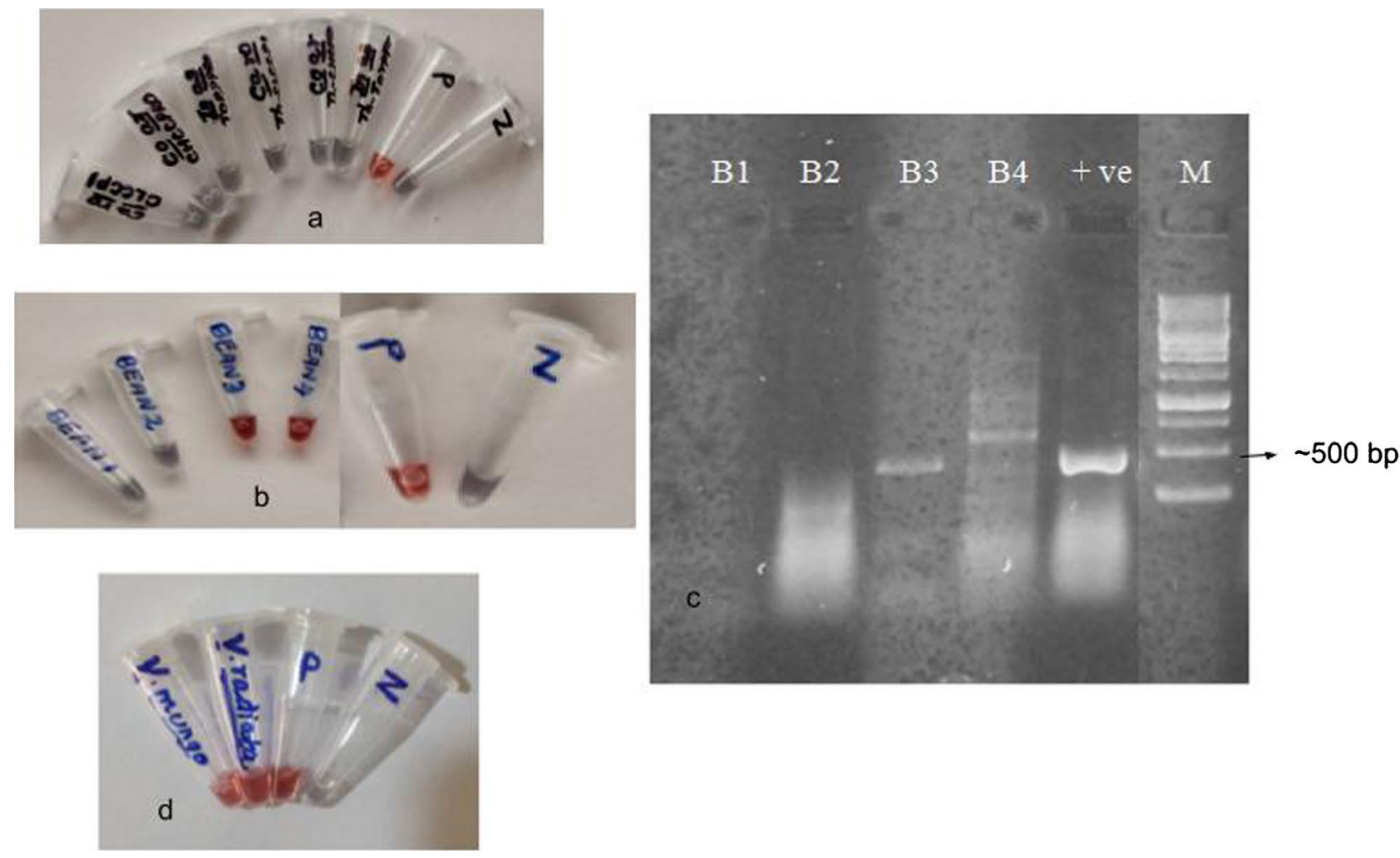

Figure 10. Specificity and versatility of AuNP assay for the probe-clccpil thiol. (a) Using unrelated plant DNA of three plants I. aspalathoides, P. amboinicus and C. roseus. (b) Using plants belonging to other family (Fabaceae) - P. vulgaris (common bean) that are infected by different begomoviruses. (c) PCR detection of begomovirus infection in bean plants (B1 to B4) using Deng primers. (d) Screening of begomovirus infected positive samples $V$. mungo (black gram) and $V$. radiata (mung bean) belonging to family Fabaceae were procured from TNAU. In $8 \mathrm{c}$, the marker lane was from the same gel, refer supplementary figure (Supplementary file).

\begin{tabular}{|l|l|}
\hline Probes & Sequence $\left(\mathbf{5}^{\prime} \rightarrow \mathbf{3}^{\prime}\right)$ \\
\hline clccpilthiol & [ThiC6]TTCCGATTCATGGGCCTGTT \\
\hline chrpprol & TTGACATCGGAGCTGGACTTTGCT \\
\hline chrpprolthiol & [ThiC6]TTGACATCGGAGCTGGACTTTGCT \\
\hline torpprol & ACTGCATTCTTGATTGCCCACTGC \\
\hline torpprolthiol & [ThiC6]ACTGCATTCTTGATTGCCCACTGC \\
\hline
\end{tabular}

Table 1. Probes used in this study.

and $\sim 600$ bp for B3 and B4 bean samples respectively (Fig. 10b,c). The clccpil thiol probe (coat protein gene) was able to detect the Mung bean yellow mosaic virus in both Vigna varieties (Fig. 10d). The probes based on replicase gene of chilli and tomato (chrpprol thiol and torppro1 thiol) were able to detect only the begomovirus of chilli and tomato respectively (data not shown).

\section{Discussion}

Screening of plants for begomovirus by PCR. The total DNA was isolated from all the plants (symptomatic and asymptomatic) under study using the Dellaporta method ${ }^{56}$. The total DNA isolated from the plants had a 260/280 ratio around 1.8-2 when analyzed in nanodrop and intact bands were observed on agarose gel. These confirmed that most of the genomic DNA was intact and could be used for PCR except for tomato samples which were pale brown to brown due to phenolics. PCR analysis of the plants (chilli and common bean) for $18 \mathrm{~S}$ rRNA and begomovirus DNA (Deng primers) showed amplification whereas tomato samples were negative for PCR analysis (both primers) (Figs. 2, 10c). The absence of bands in PCR analyses of tomato plants could be due to the excessive phenolics and polysaccharides observed in tomato DNA samples, which were known to inhibit polymerase activity ${ }^{57}$.

Previous reports on screening of begomovirus in plants have shown utilization of different primers with varied success ${ }^{58-61}$. Deng primers (Deng A and Deng B) were designed on the coat protein (CP) of begomoviruses 
as the CP gene was highly conserved across the genus ${ }^{62}$. The CP gene has a significant role in encapsidation of the viral DNA and is implicated in viral movement within the plant as well as in whitefly transmission ${ }^{9,63-65}$. Hence for PCR detection, the most common target is the begomoviral coat protein (CP) gene ${ }^{66,67}$ and hence Deng primers were utilized in this study. Among the chilli plants (99 No's) screened for begomoviral infection by PCR, 49 samples were found to be positive. The PCR with $18 \mathrm{~S}$ rRNA for all the chilli plants were found to be positive, thus confirming the absence of bands in PCR with Deng primers was due to the absence of begomovirus and not due to the presence of any inhibitors in those samples. The coat protein region of begomovirus from a PCR positive chilli plant was amplified using Deng primer, cloned and sequenced ${ }^{54}$. The sequence analysis revealed the presence of a partial coat protein sequence and was deposited in GenBank with accession number (MH500267) (Fig. 3).

Probe design. Five different probes ( 3 thiolated and 2 non-thiolated) based on coat protein ( 1 probe) and replicase protein (4 No's) of begomovirus were designed and used in this work (Table 1 ). The replicase gene probes (thiolated and non-thiolated) (Table 1) for chilli and tomato plants were designed based on GenBank sequences, FM877858.1 \& AY260505.1 respectively. The coat protein probe (thiolated) for chilli plant was designed based on the sequence obtained in this study (MH500267.1). Different probes (coat protein and replicase gene) were designed to determine if there are any differences in the detection limit or specificity among the probes.

AuNP synthesis and conjugation with probes. Gold nanoparticles (AuNPs) synthesized were cherry red in colour, average size of the unmodified AuNPs was found to be $\sim 20 \mathrm{~nm}$ and elemental analysis confirmed the presence of $\mathrm{Au}$ in the colloidal suspension (Fig. 4a). The AuNPs were then conjugated with probes either by salt-ageing method (thiolated probes) or $\mathrm{pH}$ dependent citrate method (non-thiolated probes). All the functionalized AuNPs remained red in colour thus confirming the stability of AuNPs upon functionalization with different probes. Particle size analysis and Zeta potential measurement of the functionalized AuNPs with chrppro1 thiol probe were $32.8 \mathrm{~nm}$ and $-49.9 \mathrm{mV}$ respectively, which confirmed the formation of negative charges on the surface of synthesized AuNPs. Negative charge on AuNPs is due to citrate which acts as both a reducing and a stabilizing agent that results in repulsion between AuNPs thus preventing the aggregation of AuNPs ${ }^{68}$. A narrow peak pattern revealed that functionalized gold nanoparticles possessed good stability (Fig. 5a,b).

AuNP assay. AuNP assay is based on hybridization of a specific probe (coat protein or replicase gene of begomovirus) and its target DNA (begomoviral DNA). Upon hybridization, the mixture was treated with salt to detect the presence of begomovirus. Retention of red colour indicated the presence of begomovirus as the AuNPs were protected due to hybridization of probe and viral DNA (coat protein or replicase gene). In the absence of begomovirus, the probes on the AuNPs are free and upon addition of salt, the negative charges (electron cloud) on the AuNPs get neutralized thereby resulting in a change of colour from red to purple ${ }^{55,69}$ (Fig. 6). AuNP assay with thiolated probes (clccpil thiol and chrpprol thiol) detected 77 chilli plants as infected with begomovirus and 70 samples as positive with non-thiolated probe (chrppro1). The difference in the number of positive samples between the probes (thiolated and non-thiolated) showed that thiolated probes were better than non-thiolated probes (Fig. 7a,b). This could be due to ordered and spacious arrangement of thiolated probes onto AuNPs than non-thiolated probes, as low concentrations of thiolated probes $(\sim 10 \mathrm{nM})$ were used in salt-ageing method as compared with $\mathrm{pH}$ based citrate conjugation method (non-thiolated probe- $\sim 100 \mu \mathrm{M}$ ). AuNP assay was found to be better than PCR in detecting begomoviral infection in chilli plants as AuNP assay detected 77 samples as infected whereas PCR detected only 49 samples (Fig. 7c).

AuNP assay of 79 tomato samples showed that 43 samples were infected with begomovirus. Three probes (clccpil thiol, torppro1 thiol and torppro1) were used in the assay and the thiolated probes detected an equal number of samples ( 43 No's) whereas non-thiolated probe detected 39 samples as infected (Fig. 8a-c). This showed that the AuNP assay was not affected by the presence of phenolics or polysaccharides that hamper methods like PCR due to inhibition of polymerase activity ${ }^{57}$. Recently, DNA templated 3D self-assembly of AuNPs clusters using bi-functional oligonucleotide probe was developed for tomato leaf curl virus ${ }^{68}$. Another method using LAMP PCR was developed that detected Indonesian begomovirus isolates (ToLCNDV, PepYLCIV, and TYLCKaV) simultaneously and rapidly under field conditions for routine survey ${ }^{70,71}$. But in this method, there is a need to employ a pre-ordered mix and a small instrument and it takes more than $30 \mathrm{~min}$ to complete the assay and only few samples could be assayed.

In our lab, we have developed an AuNP probe based method for the detection of BBTV in banana plants and was found to be better than PCR ${ }^{53}$. Overall, the detection efficiency of AuNP assay (77.7\%) was found to be better than PCR screening (49.4\%) in case of chilli plants. Thiolated probes (coat protein and replicase genes) were found to detect more begomoviruses than non-thiolated probes in chilli and tomato plants in AuNP assay. Among the probes, clccpil thiol (based on coat protein region of chilli leaf curl virus) was found to be unique as it was able to detect begomovirus of both chilli and tomato plants efficiently (Figs. 7, 8). Since the clccpil thiol probe was designed on the conserved region of coat protein of chilli leaf curl virus it was able to detect begomoviruses infecting chilli and tomato plants belonging to the Solanaceae family. The probes based on replicase genes of chilli and tomato (chrpprol thiol and torpprol thiol) were able to detect only begomovirus of chilli and tomato samples respectively thus confirming their specificity.

Sensitivity and specificity of AuNP assay with clccpi1 thiol. The clone (pTZCCPp3) that carried the partial coat protein gene of begomovirus was diluted in MilliQ water and used to determine the detection limit of both AuNP assay and PCR analysis (Deng primers). AuNP assay detected plasmid upto $500 \mathrm{ag} / \mu \mathrm{l}$ whereas PCR detected plasmid only upto $10 \mathrm{ng} / \mu \mathrm{l}$ (Fig. 9). This confirmed that AuNP assay had better sensitivity than PCR 
and the detection limit was similar to our earlier work with BBTV ${ }^{53}$. The specificity assay was performed with total DNA from different healthy plants not affected by begomoviruses and was found to be negative thereby confirming that the probe (clccpil thiol) was specific to begomoviral DNA and not to plant DNA (Fig. 10a).

Versatility of AuNP assay. To further validate the versatility of the clccpil thiol probe, plants belonging to Fabaceae family that are prone for begomoviral infection were also screened. Three samples viz., common bean (Phaseolus vulgaris $[\mathrm{n}=4]$ ), mung bean (Vigna radiata, $[\mathrm{n}=1])$ and black gram (Vigna mungo, $[\mathrm{n}=1]$ ) were screened. The viral infected leaves of mung bean and black gram were obtained from TNAU and served as positive controls. The AuNP assay was able to detect begomoviral infection in those samples (Fig. 10b-d) and PCR analysis (Deng primers) also correlated thus confirming the versatility. These results confirmed that clccpil thiol probe was able to detect begomoviruses infecting plants belonging to different genera (Solanaceae and Fabaceae) in a robust manner. The begomoviruses that were potentially detected by AuNP assay (with clccpil thiol) in this study are Chilli leaf curl virus (CLCV), Tomato leaf curl virus (ToLCV), Mung bean Yellow Mosaic Virus (MYMV) (Vigna radiata and Vigna mungo) and Bean Golden Yellow Mosaic Virus (BGYMV) (Phaseolus vulgaris).

Whitefly transmitted begomoviruses cause huge losses to wide varieties of crops in India and worldwide. Pepper-infecting begomoviruses occur in India, Indonesia, Africa, Mexico, Central America, and the southern United States. Begomoviruses that infect tomato are more widely distributed and seriously impact production in tropical and subtropical regions worldwide. Monopartite begomoviruses infect peppers in Asia (e.g., Chilli leaf curl virus and Pepper leaf curl Bangladesh virus) and Africa (e.g., Pepper yellow vein Mali virus), whereas the bipartite Pepper yellow leaf curl Indonesia virus occurs in Indonesia ${ }^{45,72-77}$. The importance and diversity of begomoviruses infecting Capsicum species have increased over the past 5-10 years ${ }^{72}$. On the Indian subcontinent, in particular, leaf curl disease caused by a complex of begomoviruses and beta-satellites is considered a major constraint on pepper production ${ }^{78}$. Efficient viral resistant crops are still in various development stages and the simplest and effective means of controlling and managing these pathogens is the earliest possible detection and removal of infected plants from the fields. In this context, the present study gains importance as we demonstrate a versatile method that is simple to perform, does not require amplification step and is highly sensitive than other methods like PCR, ELISA that are hampered by the presence of inhibitors like phenolics, polysaccharides.

\section{Methods}

Plant material. The leaf samples of Capsicum annuum $(\mathrm{n}=99)$, Solanum lycopersicum $(\mathrm{n}=79)$ (Family: Solanaceae) and Phaseolus vulgaris (Family: Fabaceae) $(\mathrm{n}=4)$ were collected from open fields in various regions of Tamil Nadu, India. The leaf sample from the following plants, Plectranthus amboinicus (Family: Lamiaceae) Catharanthus roseus (Family: Apocynaceae) were collected from Chennai, Tamil Nadu and Indigofera aspalathoides (Family: Fabaceae) was collected from Madurai, Tamil Nadu. The above three plants served as internal controls (plant DNA) to determine the specificity of the probes employed. For positive control, begomoviral infected leaf samples of plants belonging to the Fabaceae family (Vigna mungo $[\mathrm{n}=1]$ and Vigna radiata $[\mathrm{n}=1]$ ) were obtained from TNAU (Dr. K.K. Kumar, Associate Professor, Department of Plant Biotechnology, Tamil Nadu Agricultural University (TNAU), Coimbatore).

Statement on guidelines. Experimental research and field studies on cultivated plants comply with relevant institutional, national, and international guidelines and legislation.

Isolation of total DNA from plants. The total DNA was isolated from the plants by Dellaporta DNA isolation method ${ }^{56}$ with few modifications. Briefly, $2 \mathrm{~g}$ of leaf tissue was ground to a fine powder using liquid nitrogen, transferred to a sterile falcon tube $(50 \mathrm{ml})$ followed by the addition of $5 \mathrm{ml}$ of extraction buffer [ $100 \mathrm{mM}$ Tris (pH 8.0), $50 \mathrm{mM}$ EDTA, $500 \mathrm{mM} \mathrm{NaCl}$, and $10 \mathrm{mM} \beta$-mercaptoethanol]. The mixture was vortexed and $660 \mu \mathrm{l}$ of $10 \%$ SDS was added, mixed thoroughly and incubated at $65^{\circ} \mathrm{C}$ for $10 \mathrm{~min}$. Then, $1.6 \mathrm{ml}$ of $5 \mathrm{M}$ potassium acetate was added and centrifuged at $8000 \mathrm{rpm}$ for $15 \mathrm{~min}$ at $4{ }^{\circ} \mathrm{C}$. The supernatant was transferred to a fresh tube and an equal volume of ice-cold chloroform was added and centrifuged at $8000 \mathrm{rpm}$ for $15 \mathrm{~min}$ at $4{ }^{\circ} \mathrm{C}$. The supernatant was transferred to a fresh tube and an equal volume of ice-cold isopropanol was added, mixed and allowed to rest for 15-20 min at room temperature. The total DNA was precipitated by centrifugation at $8000 \mathrm{rpm}$ for $15 \mathrm{~min}$ at $4{ }^{\circ} \mathrm{C}$. The pellet was washed with $70 \%$ ice-cold ethanol at $8000 \mathrm{rpm}$ for $10 \mathrm{~min}$. The pellet was air-dried and resuspended in 30-50 $\mu \mathrm{l}$ of sterile distilled water. The quality and quantity of the total DNA were analyzed using Nanodrop.

Screening of begomovirus in plants by PCR. Total DNA isolated from plants (chilli-99 No's, tomato-79 No's, common bean-4 No's) were screened for begomovirus using Taq DNA Polymerase 2X Master Mix RED with $1.5 \mathrm{mM} \mathrm{MgCl}_{2}$ (Synergy Scientific) and gemini virus specific primers-Deng primers (Deng A 5' TAATATTACCKGWKGVCCSC 3' and Deng B 5' TGGACYTTRCAWGGBCCTTCACA 3') $)^{79}$ for 30 cycles and results were documented.

Cloning and sequencing of partial coat protein of begomovirus. The PCR product (Deng primers) of one of the positive samples was cloned using InsTAclone kit and E. coli DH5a was transformed as per the instructor's manual and one of the clones was sequenced ${ }^{54}$. 
Designing of probe for begomovirus detection. The probe for coat protein gene of chilli was designed based on the sequence obtained in this study and the probes for replicase gene of chilli and tomato were designed based on the GenBank sequences (FM877858.1 and AY260505.1) respectively using online tool PRIMER QUEST. Both thiolated and non-thiolated probes were obtained from Sigma Aldrich, Chennai and suspended in MilliQ water at $100 \mu \mathrm{M}$ concentration.

Functionalization of thiolated probes. The thiolated probes $(10 \mathrm{nM})$ were functionalized by treating with freshly prepared dithiothreitol (DTT) and purified as described in Kumar et al. ${ }^{53}$. Briefly, $1 \mathrm{ml}$ of $10 \mathrm{nM}$ thiolated probe was treated with $100 \mu \mathrm{l}$ of DTT and incubated for $30 \mathrm{~min}$ at RT and purified using NAP25 column as per manufacturer's instructions (GE Lifesciences) and used for conjugation of gold nanoparticles (AuNPs).

AuNP synthesis and conjugation with probes. Gold nanoparticles (AuNPs) were synthesized by citrate reduction method and conjugated with thiolated probes as described in earlier reports $s^{53}$ and stored at $4{ }^{\circ} \mathrm{C}$. One gram of gold chloride [ $\mathrm{HAuCl}_{4} \times \mathrm{H}_{2} \mathrm{O}$ (SRL, India, Cat. No. 12023)] was suspended in $1 \mathrm{ml}$ of MilliQ water and used for the synthesis of gold nanoparticles. Briefly, $50 \mathrm{ml}$ of Milli Q water and $5 \mu \mathrm{l}$ of gold chloride were mixed in a spoutless beaker and a round-bottomed flask filled with water was kept on the top to prevent evaporation. The mixture was brought to boiling temperature and $750 \mu \mathrm{l}$ of $1 \%$ trisodium citrate dihydrate (Merck) was added and boiled further for $10 \mathrm{~min}$. The mixture turned blue, then gradually to cherry red by the end of $10 \mathrm{~min}$. The AuNPs thus synthesised were allowed to cool at RT and were stored in $50 \mathrm{ml}$ falcon tube at $4{ }^{\circ} \mathrm{C}$ until further use.

The freshly synthesized AuNPs were conjugated with non-thiolated probes by $\mathrm{pH}$ dependent citrate conjugation method ${ }^{80}$ with slight modifications. To $1 \mathrm{ml}$ of AuNPs, $5 \mu$ l of non-thiolated probe $(\sim 100 \mu \mathrm{M})$ was added, vortexed gently and $20 \mu \mathrm{l}$ of $500 \mathrm{mM}$ sodium citrate- $\mathrm{HCl}(\mathrm{pH} 3)$ was added and incubated at room temperature for $3 \mathrm{~min}$. Then, $60 \mu \mathrm{l}$ of $10 \mathrm{mM}$ HEPES ( $\mathrm{pH}$ 7.6) was added, mixed by inversion and incubated at room temperature for $5 \mathrm{~min}$. The mixture was then centrifuged at 12,000 rpm for 5 to $10 \mathrm{~min}$. The pellet was suspended in $50 \mu \mathrm{l}$ of resuspension buffer [10 mM phosphate buffered saline (PBS) $\mathrm{pH} 7.4 ; 0.1 \% \mathrm{SDS}]$, covered in aluminium foil and stored at RT until use.

The freshly synthesized AuNPs were conjugated with activated thiolated probes by salt-ageing method ${ }^{81}$ with slight modifications. Briefly, to $15 \mathrm{ml}$ of AuNPs, $300 \mu \mathrm{l}$ of activated thiolated probe was added and incubated for $30 \mathrm{~min}$ in an orbital shaker at RT overnight for $90 \mathrm{rpm}$. Then, $297 \mu \mathrm{l}$ of $100 \mathrm{mM}$ phosphate buffer (pH 7) was added, followed by addition of $165 \mu \mathrm{l}$ of $10 \%$ SDS. The mixture was further incubated for $30 \mathrm{~min}$ in an orbital shaker $90 \mathrm{rpm}$ at RT. Finally, six doses of $81 \mu \mathrm{l}$ of $2 \mathrm{M} \mathrm{NaCl}$ in $100 \mathrm{mM}$ PBS (pH 7) were added to the mixture over 2 days in an orbital shaker $90 \mathrm{rpm}$ at RT. The functionalized AuNPs were purified in aliquots of $1 \mathrm{ml}$ in $1.5 \mathrm{ml}$ centrifuge tubes by centrifugation at $12,000 \mathrm{rpm}$ for $10 \mathrm{~min}$ and washed with $500 \mu \mathrm{l}$ of resuspension buffer [100 mM phosphate buffered saline (PBS) pH 7.4; 0.1\% SDS]. Finally, the functionalized AuNPs were suspended in $50 \mu \mathrm{l}$ of resuspension buffer, covered in aluminium foil and stored at RT until use.

Characterization of AuNPs. The synthesized unmodified AuNPs were characterized by Surface Electron Microscopy (SEM), Transmission Electron Microscopy (TEM) and Energy Dispersive X-ray Spectroscopy (EDX) at Sophisticated Instrument Facility (SIF), Vellore Institute of Technology (VIT). The size and zeta potential of the functionalized AuNPs were analyzed using Particle Size Analyzer (Horiba Scientific SZ-100) at TRPVB, Madhavaram, Chennai, India.

AuNP assay for begomovirus detection. The total DNA from chilli plants $(100 \pm 10 \mathrm{ng} / \mu \mathrm{l})$ were diluted (1:5), tomato plants $(100 \pm 10 \mathrm{ng} / \mu \mathrm{l})$ were diluted (1:10) with MilliQ water and utilized for AuNP assay. The assay was performed in a PCR machine (G Storm) and had the following steps-diluted total DNA (5 $\mu$ l) was denatured at $95^{\circ} \mathrm{C}$ for $5 \mathrm{~min}$ followed by addition of $5 \mu \mathrm{l}$ of functionalized AuNP and annealing was done at $65^{\circ} \mathrm{C}$ for $10 \mathrm{~min}$. Finally, $5 \mu \mathrm{l}$ of $2 \mathrm{M} \mathrm{NaCl}$ prepared in MilliQ water was added and the results were recorded within $20 \mathrm{~min}$. The DNA of begomovirus infected plants (chilli and tomato) served as positive control and healthy plant DNA (chilli and tomato) served as negative control and the principle of the assay was represented (Fig. 6)

Specificity and sensitivity of AuNP assay. To confirm the specificity and sensitivity of the assay, the plasmid (pTZCCPp3 carrying partial coat protein DNA) served as positive control and MilliQ as a negative control. The total DNA from other plants belonging to the other genera, which are not susceptible to begomovirus, Indigofera aspalathoides, Plectranthus amboinicus and Catharanthus roseus were tested against the functionalized AuNPs. The clone (pTZCCPp3) was diluted with MilliQ water, the different concentrations (100 ng/ $\mu \mathrm{l}, 10 \mathrm{ng} / \mu \mathrm{l}$, $10 \mathrm{pg} / \mu \mathrm{l}$ and $1 \mathrm{pg} / \mu \mathrm{l}$ ) were analyzed by PCR using M13 primers. Different concentrations of the clone (pTZCCPp3) $(1 \mathrm{ng} / \mu \mathrm{l}, 1 \mathrm{pg} / \mu \mathrm{l}, 500 \mathrm{fg} / \mu \mathrm{l}, 1 \mathrm{fg} / \mu \mathrm{l}, 500 \mathrm{ag} / \mu \mathrm{l}$ and $1 \mathrm{ag} / \mu \mathrm{l})$ were tested using AuNP assay.

Ethics approval and consent to participate. Institutional ethical clearance was obtained for this study, IEC-NI/14/DEC/44/75, dated December 22, 2014. Consent to participate is not applicable.

Consent for publication. The authors declare their consent for publication.

\section{Data availability}

The data and the materials used in the current study are available with the corresponding author and can be produced on need. 
Received: 27 January 2021; Accepted: 28 June 2021

Published online: 09 July 2021

\section{References}

1. Matthews, R. E. F. Host plant responses to virus infection. In Comprehensive Virology, Virus-host Interaction, Viral Invasion, Persistence and Diagnosis (eds Fraenkel-Conrat, H. \& Wagner, R. R.) 297-359 (Plenum Press, 1980).

2. Gibbs, A. \& Ohshima, K. Potyviruses and the digital revolution. Annu. Rev. Phytopathol. 48, 205-223 (2010).

3. Scholthof, K.-B.G. et al. Top 10 plant viruses in molecular plant pathology. Mol. Plant Pathol. 12, 938-954 (2011).

4. Goodman, R. M. Geminiviruses. J. Gen. Virol. 54, 9-21 (1981).

5. Varsani, A. et al. Establishment of three new genera in the family Geminiviridae: Becurtovirus, Eragrovirus and Turncurtovirus. Arch. Virol. 159, 2193-2203 (2014).

6. Varsani, A. et al. Capulavirus and Grablovirus: Two new genera in the family Geminiviridae. Arch. Virol. 162, 1819-1831 (2017).

7. Zerbini, F. M. et al. ICTV Virus taxonomy profile: Geminiviridae. J. Gen. Virol. 98, 131-133 (2017).

8. Moffat, A. S. Geminiviruses emerge as serious crop threat. Science 286, 1835-1835 (1999).

9. Hanley-Bowdoin, L., Settlage, S. B., Orozco, B. M., Nagar, S. \& Robertson, D. Geminiviruses: Models for plant DNA replication, transcription, and cell cycle regulation. Crit. Rev. Biochem. Mol. Biol. 35, 105-140 (2000).

10. Gutierrez, C. Geminiviruses and the plant cell cycle. Plant Mol. Biol. 43, 763-772 (2000).

11. Hawkes, J. G., Lester, R. N. \& Skelding, A. D. In The Biology and Taxonomy of the Solanaceae (eds Hawkes, J. G. et al.) (Academic Press, 1979).

12. Olmstead, R. G. et al. A molecular phylogeny of the Solanaceae. Taxon 57, 1159-1181 (2008).

13. Zhou, X. P., Xie, Y. \& Zhang, Z. K. Molecular characterization of a distinct begomovirus infecting tobacco in Yunnan, China. Arch. Virol. 146, 1599-1606 (2001).

14. Xie, Y., Zhou, X., Zhang, Z. \& Qi, Y. Tobacco curly shoot virus isolated in Yunnan is a distinct spe-cies of Begomovirus. Chin. Sci. Bull. 47, 199-207 (2002).

15. Mansoor, S. et al. Cotton leaf curl disease is associated with multiple monopartite begomoviruses supported by single DNA $\beta$. Arch. Virol. 148, 1969-1986 (2003).

16. Varma, A. \& Malathi, V. G. Emerging geminivirus problems: A serious threat to crop production. Ann. Appl. Biol. 142, 145-164 (2003).

17. Rojas, M. R. et al. World management of geminiviruses. Annu. Rev. Phytopathol. 56, 637-677 (2018).

18. Mishra, M. D., Raychaudhuri, S. P. \& Ashrafi, J. Virus causing leaf curl of Chilli (Capsicum annuum L.). Indian J. Microbiol. 3, 73-76 (1963).

19. Khan, Z. A. \& Khan, J. A. Characterization of a new begomovirus and betasatellite associated with chilli leaf curl disease in India. Arch. Virol. 162, 561-565 (2017).

20. Juárez, M. et al. First detection of tomato leaf curl New Delhi virus infecting Zucchini in Spain. Plant Dis. 98, 857-857 (2014).

21. Macedo, M. A. et al. First report of tomato severe rugose virus, a tomato-infecting begomovirus soybean plants in Brazil. Plant Dis. 101, 1959-1959 (2017).

22. López, M. M. et al. Are molecular tools solving the challenges posed by detection of plant pathogenic bacteria and viruses?. Curr. Issues Mol. Biol. 11, 13-46 (2009).

23. Clark, M. F. \& Adams, A. N. Characteristics of the microplate method of enzyme-linked immunosorbent assay for the detection of plant viruses. J. Gen. Virol. 34, 475-483 (1977).

24. McLaughlin, M. R., Barnett, O. W., Burrows, P. M. \& Baum, R. H. Improved ELISA conditions for detection of plant viruses. J. Virol. Methods 3, 13-25 (1981).

25. Hewings, A. D. \& D’Arcy, C. J. Maximizing the detection capability of a beet western yellows virus ELISA system. J. Virol. Methods 9, 131-142 (1984).

26. Makkouk, K. M., Hsu, H. T. \& Kumari, S. G. Detection of three plant viruses by dot-blot and tissue-blot immunoassays using chemiluminescent and chromogenic substrates. J. Phytopathol. 139, 97-102 (1993).

27. Derrick, K. S. Quantitative assay for plant viruses using serologically specific electron microscopy. Virology 56, 652-653 (1973).

28. Milne, R. G. Immunoelectron microscopy for virus identification. In Electron Microscopy of Plant Pathogens (eds Mendgen, K. \& Lesemann, D. E.) 87-102 (Springer, 1991).

29. Van Regenmortel, M. H. V. Serology and immunochemistry of plant viruses. Immunol. Commun. 11, 509-525 (1982).

30. Mullis, K. et al. Specific enzymatic amplification of DNA in vitro: The polymerase chain reaction. Cold Spring Harb. Symp. Quant. Biol. 51, 263-273 (1986).

31. Henson, J. M. \& French, R. The polymerase chain reaction and plant disease diagnosis. Annu. Rev. Phytopathol. 31, 81-109 (1993).

32. Levy, L., Hadidi, A., Kolber, M., Tokes, G. \& Nemeth, M. 3â Non-coding region RT-PCR detection and molecular hybridization of plum pox virus in anthers of infected stone fruit. Acta Hortic. 386, 331-339 (1995).

33. Candresse, T., Lanneau, M., Revers, F., Kofalvi, S. \& Macquaire, G. PCR based techniques for the detection of plant viruses and virioids. Acta Hortic. 530, 61-67 (2000).

34. Maule, A. J., Hull, R. \& Donson, J. The application of spot hybridization to the detection of DNA and RNA viruses in plant tissues. J. Virol. Methods 6, 215-224 (1983).

35. Garger, S. J. et al. Rapid detection of plant RNA viruses by dot blot hybridization. Plant Mol. Biol. Rep. 1, 21-25 (1983).

36. Owens, R. A. \& Diener, T. O. 6: Spot hybridization for detection of viroids and viruses. In Methods in Virology Vol. 7 (eds Maramorosch, K. \& Koprowski, H.) 173-187 (Elsevier, 1984).

37. Rosner, A., Lee, R. F. \& Bar-Joseph, M. Differential hybridization with cloned cDNA sequences for detecting a specific isolate of citrus tristeza virus. Phytopathology 76, 820-824 (1986).

38. Baulcombe, D. C. Detection of strains of potato virus X and of a broad spectrum of potato virus $\mathrm{Y}$ isolates by nucleic acid spot hybridization (NASH). Plant Dis. 72, 307-309 (1988).

39. Palukaitis, P. 9: Detection and characterization of subgenomic RNA in plant viruses. In Methods in Virology Vol. 7 (eds Maramorosch, K. \& Koprowski, H.) 259-317 (Elsevier, 1984).

40. Kumar, S., Jaidi, M. \& Raj, S. K. Molecular characterization of a Begomovirus and Betasatellite infecting wild sunflower (Helianthus spp.) in India. Virol. Res. 1, 1-9 (2016).

41. Saiki, R. K. et al. Primer-directed enzymatic amplification of DNA with a thermostable DNA polymerase. Science 239, 487-491 (1988).

42. Sohrab, S. S., Mandal, B., Pant, R. P. \& Varma, A. First report of association of tomato leaf curl virus-new delhi with yellow mosaic disease of Luffa cylindrica in India. Plant Dis. 87, 1148-1148 (2003).

43. Price, J. A., Smith, J., Simmons, A., Fellers, J. \& Rush, C. M. Multiplex real-time RT-PCR for detection of Wheat streak mosaic virus and Triticum mosaic virus. J. Virol. Methods 165, 198-201 (2010).

44. Araujo, R., Amorim, A. \& Gusmão, L. Diversity and specificity of microsatellites within Aspergillus section Fumigati. BMC Microbiol. 12, 154 (2012).

45. Leke, W. N., Mignouna, D. B., Brown, J. K. \& Kvarnheden, A. Begomovirus disease complex: Emerging threat to vegetable production systems of West and Central Africa. Agric. Food Secur. 4, 1 (2015). 
46. Rick, J., Tsai, M. C. \& Hwang, B. J. Biosensors incorporating bimetallic nanoparticles. Nanomaterials (Basel) 6, 5 (2016).

47. Jayanthi, V. S. P. K. S. A., Das, A. B. \& Saxena, U. Recent advances in biosensor development for the detection of cancer biomarkers. Biosens. Bioelectron. 91, 15-23 (2017).

48. Thaxton, C. S., Georganopoulou, D. G. \& Mirkin, C. A. Gold nanoparticle probes for the detection of nucleic acid targets. Clin. Chim. Acta. 363, 120-126 (2006).

49. Hutter, E. \& Fendler, J. H. Exploitation of localized surface plasmon resonance. Adv. Mater. 16, 1685-1706 (2004).

50. Liz-Marzán, L. M. Tailoring surface plasmons through the morphology and assembly of metal nanoparticles. Langmuir 22, 32-41 (2006).

51. Miller, S. A., Beed, F. D. \& Harmon, C. L. Plant disease diagnostic capabilities and networks. Annu. Rev. Phytopathol. 47, 15-38 (2009).

52. Wang, T.-M. \& Yang, J.-T. Visual DNA diagnosis of Tomato yellow leaf curl virus with integrated recombinase polymerase amplification and a gold-nanoparticle probe. Sci. Rep. 9, 15146 (2019).

53. Kumar, P., Arun, V. \& Lokeswari, T. S. Cloning of BBTV (Banana Bunchy Top Virus) components and screening of BBTV using functionalized gold nanoparticles. 3 Biotech 7, 225 (2017).

54. Lavanya, R. \& Arun, V. Standardization of DNA extraction protocol and screening of begomovirus in chilli and tomato plants. J. Plant Dis. Prot. 42, 265 (2019).

55. Doria, G., Franco, R. \& Baptista, P. Nanodiagnostics: Fast colorimetric method for single nucleotide polymorphism/mutation detection. IET Nanobiotechnol. 1, 53-57 (2007).

56. Dellaporta, S. L., Wood, J. \& Hicks, J. B. A plant DNA minipreparation: Version II. Plant Mol. Biol. Rep. 1, 19-21 (1983).

57. Fang, G., Hammar, S. \& Grumet, R. A quick and inexpensive method for removing polysaccharides from plant genomic DNA. Biotechniques 13, 52-54 (1992).

58. Wasswa, P. et al. First identification of a sweet potato begomovirus (sweepovirus) in Uganda: Characterization, detection and distribution. Plant Pathol. 60, 1030-1039 (2011).

59. Jitendra, K. \& Rabindran, R. Detection of gemini virus in cassava and differentiation between SLCMV and ICMV by multiplex PCR. Int. J. Agric. Sci. 10, 5255-5259 (2018).

60. Saha, A., Saha, B. \& Saha, D. Molecular detection and partial characterization of a begomovirus causing leaf curl disease of potato in sub-Himalayan West Bengal, India. J. Environ. Biol. 35, 601-606 (2014).

61. Bandaranayake, W. M. E. K., Wickramarachchi, W. A. R. T., Wickramasinghe, H. A. M., Rajapakshe, R. G. A. S. \& Dissanayake, D. M. K. K. Molecular detection and characterization of begomoviruses associated with cucurbitaceae vegetables in Sri Lanka. J. Natl. Sci. Found. Sri Lanka. 42, 265-271 (2014).

62. Idris, A. M. \& Brown, J. K. Sinaloa tomato leaf curl geminivirus: Biological and molecular evidence for a new subgroup III virus. Phytopathology 88, 648-657 (1998).

63. Wartig, L. et al. Genetic analysis of the monopartite tomato yellow leaf curl geminivirus: Roles of V1, V2, and C2 ORFs in viral pathogenesis. Virol 228, 132-140 (1997).

64. Harrison, B. D. \& Robinson, D. J. Natural genomic and antigenic variation in whitefly-transmitted geminiviruses (begomoviruses). Annu. Rev. Phytopathol. 37, 369-398 (1999).

65. Sharma, P. \& Ikegami, M. Characterization of signals that dictate nuclear/nucleolar and cytoplasmic shuttling of the capsid protein of Tomato leaf curl Java virus associated with DNA $\beta$ satellite. Virus Res. 144, 145-153 (2009).

66. Brown, J. K., Idris, A. M., Torres-Jerez, I., Banks, G. K. \& Wyatt, S. D. The core region of the coat protein gene is highly useful for establishing the provisional identification and classification of begomoviruses. Arch. Virol. 146, 1581-1598 (2001).

67. Wyatt, S. D. \& Brown, J. K. Detection of subgroup III geminivirus isolates in leaf extracts by degenerate primers and polymerase chain reaction. Phytopathology 86, 1288-1293 (1996).

68. Dharanivasan, G. et al. DNA templated self-assembly of gold nanoparticle clusters in the colorimetric detection of plant viral DNA using a gold nanoparticle conjugated bifunctional oligonucleotide probe. RSC Adv. 6, 11773-11785 (2016).

69. Shawky, S. M., Bald, D. \& Azzazy, H. M. E. Direct detection of unamplified hepatitis C virus RNA using unmodified gold nanoparticles. Clin. Biochem. 43, 1163-1168 (2010).

70. Wilisiani, F. et al. New recombinant of tomato leaf curl new delhi virus infecting melon in Indonesia. J. Gen. Plant Pathol. 85, 306-310 (2019).

71. Wilisiani, F. et al. Development of a LAMP assay with a portable device for real-time detection of begomoviruses under field conditions. J. Virol. Methods 265, 71-76 (2019).

72. Kenyon, L., Tsai, W. S., Shih, S. L. \& Lee, L. M. Emergence and diversity of begomoviruses infecting solanaceous crops in East and Southeast Asia. Virus Res. 186, 104-113 (2014).

73. Sakata, J. J., Shibuya, Y., Sharma, P. \& Ikegami, M. Strains of a new bipartite begomovirus, pepper yellow leaf curl Indonesia virus, in leaf-curl-diseased tomato and yellow-vein-diseased ageratum in Indonesia. Arch. Virol. 153, 2307-2313 (2008).

74. Shih, S. L. et al. Molecular characterization of tomato and chili leaf curl begomoviruses from Pakistan. Plant Dis. 87, 200-200 (2003).

75. Tahir, M., Haider, M. S. \& Briddon, R. W. Chili leaf curl betasatellite is associated with a distinct recombinant begomovirus, Pepper leaf curl Lahore virus, Capsicum in Pakistan. Virus Res. 149, 109-114 (2010).

76. Tiendrébéogo, F. et al. Molecular and biological characterization of Pepper yellow vein Mali virus (PepYVMV) isolates associated with pepper yellow vein disease in Burkina Faso. Arch. Virol. 156, 483-487 (2011).

77. Zhou, Y. C. et al. Evidence of local evolution of tomato-infecting begomovirus species in West Africa: Characterization of tomato leaf curl Mali virus and tomato yellow leaf crumple virus from Mali. Arch. Virol. 153, 693-706 (2008).

78. Kumar, R. V. et al. Complexity of begomovirus and betasatellite populations associated with chilli leaf curl disease in India. J. Gen. Virol. 96, 3143-3158 (2015).

79. Deng, D., McGrath, P. F., Robinson, D. J. \& Harrison, B. D. Detection and differentiation of whitefly-transmitted geminiviruses in plants and vector insects by the polymerase chain reaction with degenerate primers. Ann. Appl. Biol. 125, 327-336 (1994).

80. Zhang, X., Servos, M. R. \& Liu, J. Surface science of DNA adsorption onto citrate-capped gold nanoparticles. Langmuir 28, 3896-3902 (2012).

81. Hill, H. D. \& Mirkin, C. A. The bio-barcode assay for the detection of protein and nucleic acid targets using DTT-induced ligand exchange. Nat. Protoc. 1, 324-336 (2006).

\section{Acknowledgements}

The authors are grateful for SRIHER management for the Founder Chancellor Sri N.P.V. Ramasamy Udayar Research Fellowship (2013-16).

\section{Author contributions}

L.R. performed bench works, worked on the study design and flow, performed analysis and wrote the manuscript. A.V. performed conception and designed the study, analysed the data, supported for patent filing and analysed the manuscript. All the authors read and approved the final manuscript. 


\section{Competing interests}

The authors declare no competing interests.

\section{Additional information}

Supplementary Information The online version contains supplementary material available at https://doi.org/ 10.1038/s41598-021-93615-9.

Correspondence and requests for materials should be addressed to V.A.

Reprints and permissions information is available at www.nature.com/reprints.

Publisher's note Springer Nature remains neutral with regard to jurisdictional claims in published maps and institutional affiliations.

(c) (1) Open Access This article is licensed under a Creative Commons Attribution 4.0 International License, which permits use, sharing, adaptation, distribution and reproduction in any medium or format, as long as you give appropriate credit to the original author(s) and the source, provide a link to the Creative Commons licence, and indicate if changes were made. The images or other third party material in this article are included in the article's Creative Commons licence, unless indicated otherwise in a credit line to the material. If material is not included in the article's Creative Commons licence and your intended use is not permitted by statutory regulation or exceeds the permitted use, you will need to obtain permission directly from the copyright holder. To view a copy of this licence, visit http://creativecommons.org/licenses/by/4.0/.

(C) The Author(s) 2021 